\title{
Synthesis of biocompatible iron oxide nanoparticles as a drug delivery vehicle
}

This article was published in the following Dove Press journal: International Journal of Nanomedicine

\section{Krupa Kansara \\ Pal Patel \\ Ritesh K Shukla \\ Alok Pandya \\ Rishi Shanker \\ Ashutosh Kumar \\ Alok Dhawan}

Institute of Life Sciences, School of Science and Technology, Ahmedabad University, Ahmedabad, Gujarat, India

\begin{abstract}
Over the last decade, there has been growing interest in developing novel nanoparticles (NPs) for biomedical applications. A safe-by-design approach was used in this study to synthesize biocompatible iron oxide NPs. The size of the particles obtained was $\sim 100 \mathrm{~nm}$. Although these NPs were significantly $(P<0.05)$ internalized in MCF-7 (human breast adenocarcinoma cell line) cells, no adverse effect was observed in the cells as assessed by cytotoxicity assays (neutral red uptake and 3-[4,5-dimethylthiazol-2-yl]-2,5-diphenyltetrazolium bromide) and cell cycle analysis. Our data demonstrate the potential of iron oxide NPs as a biocompatible carrier for targeted drug delivery. Keywords: biocompatible iron oxide nanoparticles, human breast adenocarcinoma cells, coprecipitation
\end{abstract}

\section{Introduction}

Iron-based magnetic nanoparticles (NPs) such as magnetite $\left(\mathrm{Fe}_{3} \mathrm{O}_{4}\right)$ have been studied in detail due to their unique properties, such as stability over time, biocompatibility, and sensitivity to magnetic field. ${ }^{1-3}$ They can potentially be used as magnetic targeted drug delivery carriers and magnetic resonance imaging contrast agents due to their high saturation magnetization, low toxicity, and biocompatibility. ${ }^{4}$ The magnetic properties of $\mathrm{Fe}_{3} \mathrm{O}_{4}$ NPs are attributed to their size and size distribution, which, in turn, is dependent on the route of synthesis.

Therefore, in this study, an attempt was made to synthesize $\mathrm{Fe}_{3} \mathrm{O}_{4}$ NPs using a safe-by-design approach by the coprecipitation method. Polyethylene glycol (PEG) was used as surfactant to control the particle size and narrow size distribution. The biocompatibility of $\mathrm{Fe}_{3} \mathrm{O}_{4}$ NPs was evaluated by cytotoxicity assays and cell cycle analysis in the human breast adenocarcinoma cell line (MCF-7).

\section{Materials and methods Materials}

Ferric chloride hexahydrate and ferrous sulfate were purchased from SD-Fine-Chem. Ltd, Mumbai, India. Ployetheleneglycol (PEG-6000), dimethylesulphoxide, sodium hydroxide $(\mathrm{NaOH})$, minimum essential medium eagle, phosphate-buffered saline, 3-(4,5-dimethylthiazol-2-yl)-2,5-diphenyltetrazolium bromide (MTT), and antibiotic-antimycotic solution were purchased from HiMedia Laboratories Pvt. Ltd., (Mumbai, India). The MCF-7 cell line was purchased from the National Centre for Cell Sciences, Pune, India.

\section{$\mathrm{Fe}_{3} \mathrm{O}_{4} \mathrm{NP}$ synthesis}

The preparation of $\mathrm{Fe}_{3} \mathrm{O}_{4}$ NPs was performed by a chemical coprecipitation method of $\mathrm{Fe}^{2+}$ and $\mathrm{Fe}^{3+}$ ions (1:2 molar ratios) by the addition of $\mathrm{NaOH} .{ }^{5}$ A total volume of $15 \mathrm{~mL}$ 


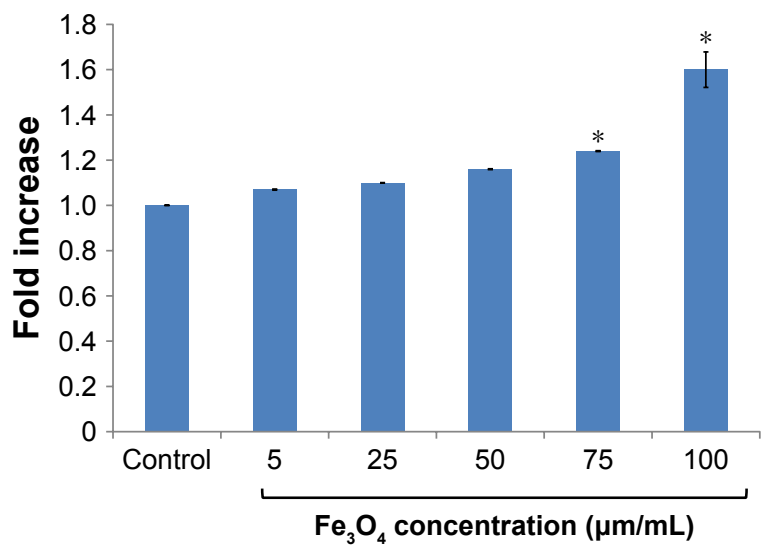

Figure I Internalization of $\mathrm{Fe}_{3} \mathrm{O}_{4} \mathrm{NPs}$ in MCF-7 cells using flow cytometry. Notes: Data are expressed as mean \pm standard error of the mean from three independent experiments. $* P<0.05$, when compared with control.

Abbreviations: NPs, nanoparticles; MCF-7, human breast adenocarcinoma cell line.

of $0.25 \mathrm{M} \mathrm{Fe}^{2+}$ and $0.5 \mathrm{M} \mathrm{Fe}^{3+}$ solutions were prepared in deionized water. PEG was then added and the temperature slowly risen up to $80^{\circ} \mathrm{C}$. During the initial 2 minutes of the reaction, $\mathrm{NaOH}$ was added to achieve a $\mathrm{pH}$ of 10 . The reaction was allowed to continue on a magnetic stirrer for 2 hours. Thereafter, the suspension was centrifuged and washed several times with deionized water to lower the $\mathrm{pH}$ to 7 . Finally, the particles were suspended in $10 \mathrm{~mL}$ of dimethylesulphoxide.

\section{Characterization of $\mathrm{Fe}_{3} \mathrm{O}_{4} \mathrm{NPs}$}

One milliliter of the stock suspension of $\mathrm{Fe}_{3} \mathrm{O}_{4}$ NPs was diluted in $10 \mathrm{~mL}$ complete minimum essential medium eagle. The hydrodynamic size and zeta potential were determined using Zetasizer Nano ZS.

\section{Cytotoxicity assessment}

The cytotoxic potential of $\mathrm{Fe}_{3} \mathrm{O}_{4}$ NPs was assessed in MCF-7 cells after 6 and 24 hours of treatment using MTT and neutral

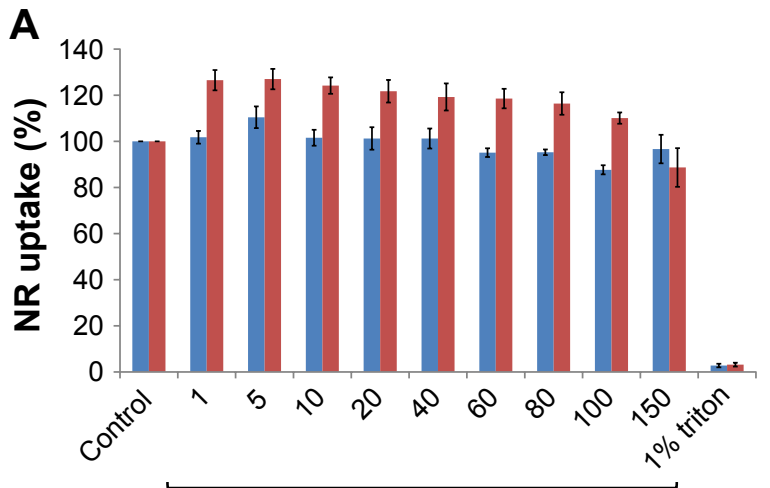

$\mathrm{Fe}_{3} \mathrm{O}_{4} \mathrm{NPs}(\mu \mathrm{M} / \mathrm{mL})$ red uptake (NRU) assays as described by Mosmann ${ }^{6}$ and Borenfreund and Puerner, respectively. ${ }^{7}$

\section{Cellular internalization of NPs}

The internalization of $\mathrm{Fe}_{3} \mathrm{O}_{4} \mathrm{NPs}$ in MCF-7 cells was assessed according to the method described in our earlier study. ${ }^{8}$

\section{Cell cycle analysis}

The effect of $\mathrm{Fe}_{3} \mathrm{O}_{4}$ NPs on cell cycle was assessed according to the method described in our earlier study. ${ }^{8}$

\section{Results and discussion}

The mean hydrodynamic size and zeta potential of synthesized $\mathrm{Fe}_{3} \mathrm{O}_{4}$ NPs were $98.19 \pm 1.0 \mathrm{~nm}$ and $36 \pm 2 \mathrm{mV}$, respectively. Flow cytometric analysis revealed a significant $(P<0.05)$ increase in the internalization of $\mathrm{Fe}_{3} \mathrm{O}_{4}$ NPs in MCF-7 cells after 24 hours exposure at the two higher concentrations, as evident by an increase in the side scatter intensity (Figure 1).

In the cytotoxicity assays, namely NRU and MTT, $\mathrm{Fe}_{3} \mathrm{O}_{4}$ NPs were found to be biocompatible as there was no significant increase in the NRU $(88 \%$ at concentration $150 \mu \mathrm{M} / \mathrm{mL})$ and a reduction (96\%) in the mitochondrial succinate dehydrogenase activity was observed at the highest concentration after 24-hour exposure (Figures 2A and B).

Additionally, no change in cell cycle progression was observed in $\mathrm{Fe}_{3} \mathrm{O}_{4}$ NPs-treated MCF-7 cells, after 24-hour exposure (Figure 3).

\section{Conclusion}

Our results demonstrated that $\mathrm{Fe}_{3} \mathrm{O}_{4}$ NPs synthesized using the safe-by-design approach showed no adverse effect on cells, as assessed by cytotoxicity assays and cell cycle analysis in MCF-7 cells, even though they are significantly

B

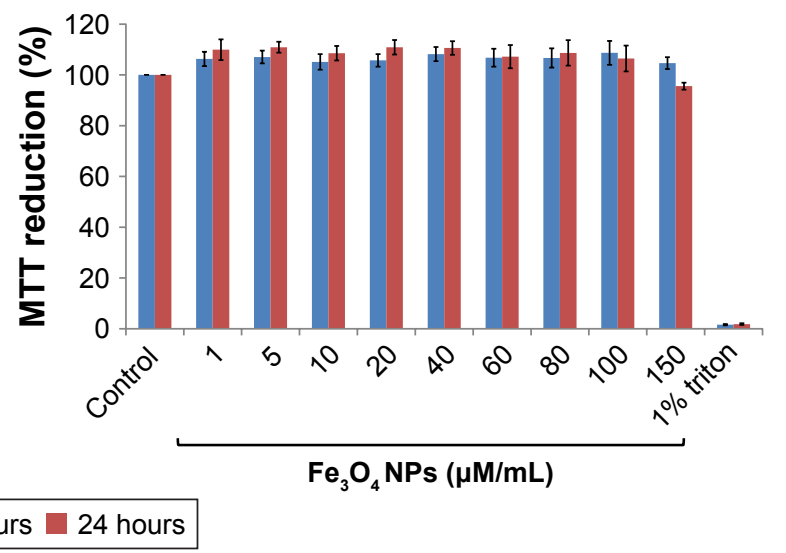

Figure 2 Cytotoxicity of $\mathrm{Fe}_{3} \mathrm{O}_{4}$ NPs in MCF-7 cells. (A) NR uptake (\%); (B) MTT reduction (\%).

Notes: The viability of the control cells was considered as 100\%. Data are expressed as mean \pm standard error of the mean from three independent experiments.

Abbreviations: NPs, nanoparticles; MCF-7, human breast adenocarcinoma cell line; MTT, 3-(4,5-dimethylthiazol-2-yl)-2,5-diphenyltetrazolium bromide; NR, neutral red. 

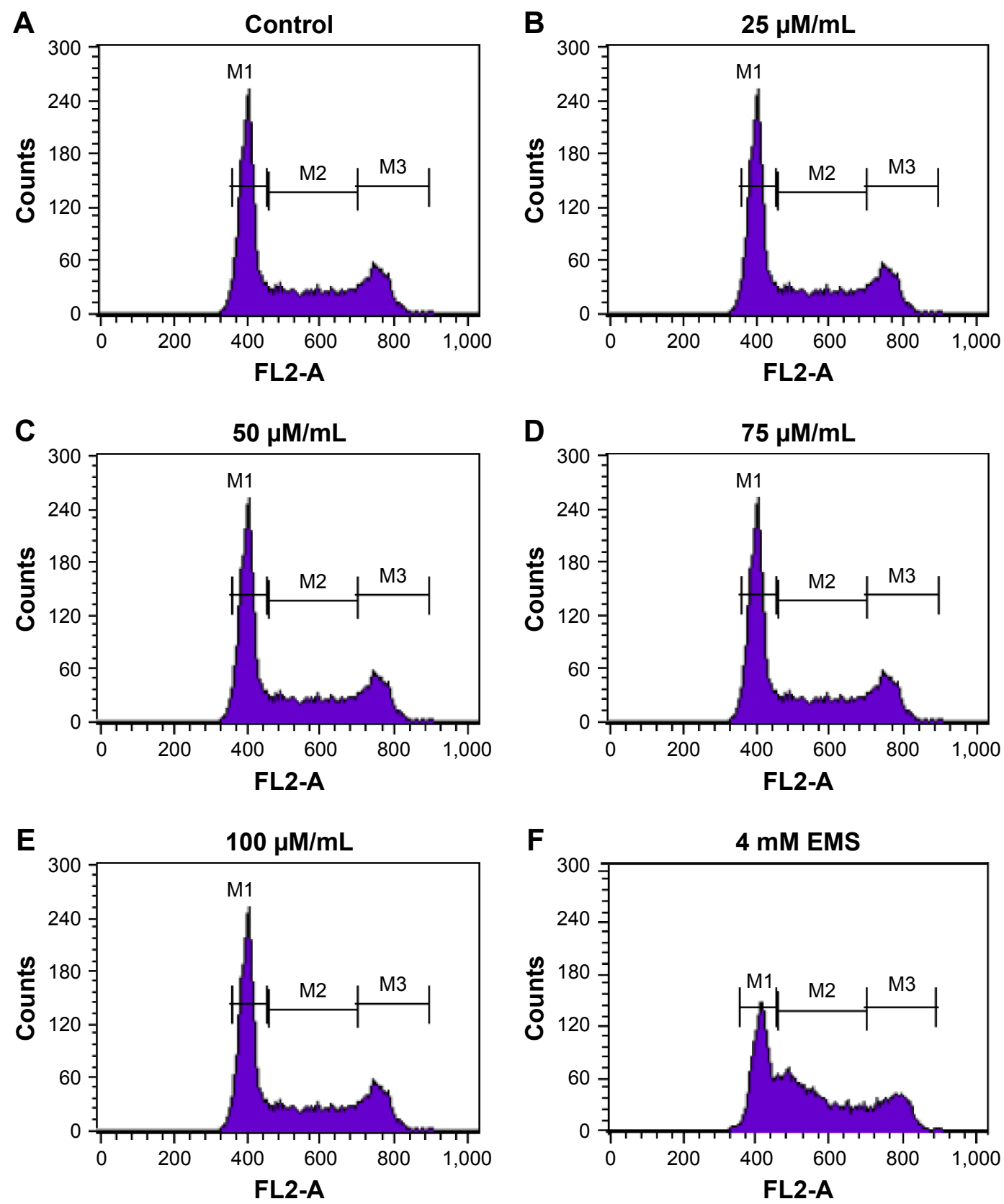

Figure 3 Effect of $\mathrm{Fe}_{3} \mathrm{O}_{4} \mathrm{NPs}$ on cell cycle progression in MCF-7 cells $(\mathbf{A})$ control (B-E) cells treated with different concentration of $\mathrm{Fe}_{3} \mathrm{O}_{4} \mathrm{NPs}_{\text {s }}$ and $(\mathbf{F})$ cells treated with 4 mM EMS.

Abbreviations: EMS, ethylmethane sulfonate; NPs, nanoparticles; MCF-7, human breast adenocarcinoma cell line.

internalized. Therefore, these NPs have a potential to be used as a carrier for targeted drug delivery.

\section{Acknowledgments}

The authors acknowledge the funding from the Centre for Nanotechnology Research and Application (CENTRA) by The Gujarat Institute for Chemical Technology (GICT); and the European Union Seventh Framework Programme (FP7/2007-2013) under grant agreement number 263147 (NanoValid - Development of reference methods for hazard identification, risk assessment and LCA of engineered nanomaterials).

\section{Disclosure}

The authors report no conflicts of interest in this work.

\section{References}

1. Chin SF, Iyer, KS, Saunders M, et al. Encapsulation and sustained release of curcumin using superparamagnetic silica reservoirs. Chemistry. 2009; 15(23):5661-5665.

2. Liu G, Wang Z, Lu J, et al. Low molecular weight alkyl-polycation wrapped magnetite nanoparticle clusters as MRI probes for stem cell labelling and in vivo imaging. Biomaterials. 2011;32(2):528-537.

3. Dandamudi S, Campbell RB. The drug loading, cytotoxicity and tumor vascular targeting characteristics of magnetite in magnetic drug targeting. Biomaterials. 2007;28(31):4673-4683. 
4. Pan BF, Gao F, Gu HC. Dendrimer modified magnetite nanoparticles for protein immobilization. J ColloidInterface Sci. 2005;284(1):1-6.

5. Hariani PL, Faizal M, Ridwan, Marsi, Setiabudidaya D. Synthesis and properties of $\mathrm{Fe}_{3} \mathrm{O}_{4}$ nanoparticles by co-precipitation method to removal procion dye. Int J Environ Sci Develop. 2013;4(3):336-340.

6. Mosmann T. Rapid colorimetric assay for cellular growth and survival: application to proliferation and cytotoxicity assay. J Immunol Methods. 1983;65(1-2):55-63.

7. Borenfreund $\mathrm{E}$, Puerner E. Toxicity determined in vitro by morphological alterations and neutral red absorption. Toxicol Lett. 1985;24(2-3): $119-124$.
8. Kansara K, Patel P, Shah D, et al. TiO2 nanoparticles induce DNA double strand breaks and cell cycle arrest in human alveolar cells. Environ Mol Mutagen. 2015;56(2):204-217.

International Journal of Nanomedicine

\section{Publish your work in this journal}

The International Journal of Nanomedicine is an international, peerreviewed journal focusing on the application of nanotechnology in diagnostics, therapeutics, and drug delivery systems throughout the biomedical field. This journal is indexed on PubMed Central, MedLine, CAS, SciSearch $\AA$, Current Contents ${ }^{\circledR} /$ Clinical Medicine,
Journal Citation Reports/Science Edition, EMBase, Scopus and the Elsevier Bibliographic databases. The manuscript management system is completely online and includes a very quick and fair peer-review system, which is all easy to use. Visit http://www.dovepress.com/ testimonials.php to read real quotes from published authors.

Submit your manuscript here: http://www.dovepress.com/international-journal-of-nanomedicine-journal 